Bartosz Szczurowski

Uniwersytet Jagielloński

\title{
SPOSOBY UREGULOWANIA KWESTII ZASTĘPSTWA GŁOWY PAŃSTWA W RAZIE OPRÓŻNIENIA URZĘDU LUB PRZEJŚCIOWEJ NIEMOŻNOŚCI JEGO SPRAWOWANIA WE WSPÓŁCZESNYCH REPUBLIKACH. ROZWIAZZANIA „TYPOWE” I „ORYGINALNE”
}

\section{Wstęp}

W każdym państwie mogą wystąpić sytuacje nadzwyczajne mogące zakłócić jego normalne funkcjonowanie. Jednym $\mathrm{z}$ takich zdarzeń jest niewątpliwie sytuacja, w której urząd głowy państwa zostaje opróżniony przed upływem przewidzianej kadencji, bądź też piastun tego urzędu nie może przejściowo sprawować swych obowiązków. Niezależnie od konstytucyjnej pozycji głowy państwa, choćby krótkotrwałe przerwanie funkcjonowania jakiegokolwiek organu władzy państwowej może mieć istotne niekorzystne konsekwencje. W szczególności nie byłoby bowiem wówczas podmiotu, który miałby wykonywać kompetencje głowy państwa w sytuacji, gdyby zaistniała konieczność ich wykorzystania ${ }^{1}$ (przykładowo rola Prezydenta RP w zarządzaniu wyborów parlamentarnych jest raczej formalna - jednak gdyby np. piastun urzędu prezydenckiego nie mógł sprawować swych obowiązków w czasie, gdy konieczne byłoby dokonanie takiego aktu urzędowego, wybory do Sejmu i Senatu nie mogłyby się odbyć w konstytucyjnym terminie). Aby zatem takie esktraodrynaryjne zdarzenia nie wywołały poważnych, czy wręcz nieodwracalnych szkód, większość państw zawarło w swych konstytucjach odpowiednie rozwiązania mające przeciwdziałać takim skutkom. O tym, iż tego rodzaju działania nie są jedynie przesadną ostrożnością dobitnie i niestety tragicznie przekonała śmierć Prezydenta RP Lecha Kaczyńskiego w katastrofie lotniczej pod Smoleńskiem w 2010 r.

Przedmiotem niniejszego artykułu jest przedstawienie panoramy rozwiązań funkcjonujących odnośnie zastępstwa głowy państwa w poszczególnych państwach

1 M. Zubik, Gdy Marszałek Sejmu jest pierwszą osobą w państwie, czyli polskie interregnum, „Przegląd Sejmowy” 2010, nr 5, s. 72-73. 
w sytuacji opróżnienia urzędu przed upływem kadencji lub wystąpienia przejściowej niemożności jego sprawowania przez aktualnego piastuna. Poza jego zakresem pozastawiam kwestie zastępstwa głowy państwa w sytuacji, gdy piastun tego urzędu zostaje zawieszony w jego sprawowaniu na skutek postawienia go w stan oskarżenia w procedurze egzekwowania odpowiedzialności konstytucyjnej, gdyż wymagałoby to rozważań dotyczących kształtu takiej procedury - a nawet ogólnikowe odniesienie się do tego zagadnienia zawężyłoby znacznie rozmiary niniejszego opracowania. Swoje rozważania odnoszę również jedynie do rozwiązań funkcjonujących w państwach republikańskich. Instytucja regencji funkcjonująca $\mathrm{w}$ razie niepełnoletności monarchy lub jego niezdolności do sprawowania władzy, mimo oczywistych podobieństw do procedury zastępstwa republikańskiej głowy państwa, charakteryzuje się jednak swoją specyfiką - co jest z kolei pochodną szczególnego charakteru władzy monarchy, panującego wszak dożywotnio i stąd jej omówienie wymagałoby w moim przekonaniu osobnego opracowania.

Celem niniejszego artykułu nie jest oczywiście omawianie wszystkich funkcjonujących aktualnie regulacji konstytucyjnych odnoszących się do omawianej materii. Jest nim przede wszystkim analiza, czy w obrębie danego obszaru geograficznego można mówić o istnieniu w tym zakresie jakichś rozwiązań „, typowych”. Dlatego też artykuł jest podzielony na części dotyczące takich określonych obszarów. Równocześnie przedmiotem moich rozważań jest również wskazanie na istnienie rozwiązań „oryginalnych”, które po pierwsze wykazują odrębność zarówno od regulacji powszechnie funkcjonującej w danej części świata, jak również są specyficzne „same w sobie”, gdyż nie da się ich przyporządkować do jakiegokolwiek „modelu”.

\section{Europa}

Ogólna ocena rozwiązań występujących w państwach europejskich prowadzi do wniosku, iż na kontynencie tym można mówić o wykształceniu się modelu, w którym zastępstwo republikańskiej głowy państwa jest sprawowane przez przewodniczącego parlamentu bądź jednej z jego izb (jeśli w danym państwie parlament ma charakter dwuizbowy). Rozwiązanie takie przyjmuje bowiem zdecydowanie większość państw kontynentu. Wyjątkowy charakter na tym tle mają regulacje konstytucyjne na Białorusi ${ }^{2}$, w Finlandii ${ }^{3}$ i w Rosji ${ }^{4}$, w których zastępstwo prezydenta jest sprawowane przez szefów rządów tych państw. Z kolei w Austrii zastępstwo pre-

2 Art. 89 Konstytucji Białorusi z 1994 r. wersja angielska https://www.constituteproject.org/constitution/Belarus_2004\#s254 (data dostępu: 12.06.2015 r.).

3 Art. 59 Konstytucji Finlandii z 1999 r., (w:) Konstytucje państw Unii Europejskiej, W. Staśkiewicz (red.), Warszawa 2011, s. 260.

4 Art. 92 Konstytucji Federacji Rosyjskiej z 1993 r., (w:) Konstytucja Rosji. tłum. A. Kubik, wstęp A. Bosiacki, Warszawa 2000, s. 67. 
zydenta co do zasady jest wykonywane przez kanclerza, jednak gdyby przeszkoda w sprawowaniu urzędu prezydenckiego trwała dłużej niż 20 dni, funkcje prezydenta wykonywać ma kolegium w którego skład wchodzą: przewodniczący oraz pierwszy i drugi zastępca przewodniczącego Rady Narodowej. Kolegium to sprawuje zastępstwo prezydenta także, gdyby urząd ten stał się trwale nieobsadzony ${ }^{5}$. W Czechach w razie wystąpienia konieczności takiego zastępstwa kompetencje prezydenta są w sposób precyzyjny dzielone pomiędzy dwa podmioty - szefa rządu i przewodniczącego Izby Poselskiej ${ }^{6}$. Podobna regulacja zawarta została także w konstytucji Słowacji, jednak tam określone kompetencje prezydenta wykonuje wówczas obok premiera i przewodniczącego parlamentu także rząd in corpore ${ }^{7}$. Za oryginalną należy uznać regulację zawartą w konstytucji Irlandii, w myśl której zastępstwo prezydenta sprawuje specjalna komisja złożona z przewodniczących obu izb parlamentu i prezesa sądu najwyższego ${ }^{8}$. Zbliżone rozwiązanie zastosowane zostało także w Islandii, gdzie w razie takiej konieczności obowiązki prezydenta wykonują wspólnie premier, przewodniczący parlamentu i przewodniczący sądu najwyższego ${ }^{9}$.

Specyficzny (i to nie tylko na tle rozwiązań funkcjonujących w Europie) charakter ma również unormowanie konstytucji maltańskiej, zgodnie z którym wyznaczenie osoby zastępującej prezydenta musi zostać dokonane przez premiera, który wszakże przed podjęciem decyzji musi przeprowadzić konsultacje z przywódcą opozycji ${ }^{10}$.

Należy wskazać, iż w przypadku opróżnienia urzędu prezydenckiego w większości państw europejskich procedura zastępstwa jest wykonywana jedynie do czasu wyboru nowego prezydenta, który następuje na nową kadencję, nie zaś na okres, który pozostał do końca kadencji prezydenta, który „opróżnił” urząd. Osoba zastępująca nie staje się zatem prezydentem. Wyjątkiem od tego modelu jest Bułgaria, której konstytucja przewiduje istnienie urzędu wiceprezydenta wybieranego razem z prezydentem w wyborach powszechnych ${ }^{11}$. Gdyby doszło do opróżnienia urzędu Prezydenta Bułgarii, wiceprezydent przejmuje funkcję prezydenta i sprawuje ją przez okres, jaki pozostał do zakończenia kadencji.

W konstytucjach państwa europejskich rzadko występują uregulowania sytuacji, w której osoba mająca sprawować zastępstwo prezydenta również nie jest 2011, s. 252.

$6 \quad$ Art. 66 Konstytucji Czech z 1992 r., (w:) Konstytucje państw Unii..., op. cit., s. 200.

$7 \quad$ Art. 105 Konstytucji Słowacji z 1992 r., (w:) Konstytucje państw Unii..., op. cit., s. 712.

$8 \quad$ Art. 14 Konstytucji Irlandii z 1937 r., (w:) Konstytucje państw Unii..., op. cit., s. 398-399.

$9 \quad$ Artykuł 8 Konstytucji Islandii z 1944 r., (w:) Konstytucja Islandii, tłum. i wstęp J. Osiński, Warszawa 2000, s. 67.

10 Artykuł 49 Konstytucji Malty z 1964 r., (w:) Konstytucje państw Unii..., op. cit., s. 487.

11 Art. 97 Konstytucji Bułgarii z 1991 r., (w:) Konstytucja Bułgarii, tłum. A. Kubik, wstęp J. Karp, Warszawa 2012, s. 84 - Istnienie instytucji wiceprezydenta przewiduje także konstytucja Cypru, jednak nie jest on osobą, która ma zastępować prezydenta, lecz wspólnie z nim sprawować władzę wykonawczą. Wiceprezydent ma być bowiem reprezentantem społeczności tureckiej na Cyprze. Zastępstwo prezydenta i wiceprezydenta jest sprawowane przez przewodniczącego lub wiceprzewodniczącego parlamentu. Na skutek faktycznego podziału Cypru na część grecką i turecką stanowisko wiceprezydenta nie zostało zresztą w praktyce nigdy obsadzone - zob. M. Florczak-Wątor, P. Mikuli, Systemy Konstytucyjne Cypru i Malty, Warszawa 2009, s. 33. 
zdolna do pełnienia tej funkcji. Konstytucja Francji ${ }^{12}$ przewiduje, iż w razie niemożności sprawowania zastępstwa prezydenta przez przewodniczącego Senatu kompetencja ta przechodzi w ręce rządu. Z kolei konstytucja Grecji stanowi, iż w razie „nieobecności” przewodniczącego Izby Deputowanych zastępstwo prezydenta wykonuje przewodniczący poprzedniej Izby Deputowanych, a w razie jego odmowy lub nieobecności obowiązki Prezydenta Republiki wykonuje kolegialnie rząd ${ }^{13}$. Zgodnie z konstytucją Finlandii, jeżeli premier nie może sprawować zastępstwa głowy państwa, przechodzi ono na ministra piastującego funkcję zastępcy premiera ${ }^{14}$. Szczegółowe regulacje dotyczące zastępstwa członków Komisji działającej zamiast głowy państwa zawiera także ustawa zasadnicza Irlandii ${ }^{15}$.

\section{Ameryka Północna}

Na wstępie zaznaczyć należy, iż w części dotyczącej obszaru Ameryk Północnej przedstawię również rozwiązania funkcjonujące w państwach basenu Morza Karaibskiego. Podkreślić należy, iż liczba tych państw nie jest znaczna, gdyż obszar kontynentu północnoamerykańskiego zajmują jedynie trzy państwa - z czego w dwóch istnieje republikańska forma rządów. Znaczna zaś część państw basenu Morza Karaibskiego należy do Wspólnoty Brytyjskiej i głową państwa jest w nich monarcha brytyjski.

Oczywiście, najbardziej doniosłe znaczenie ma regulacja zawarta w konstytucji USA. Zgodnie z nią zastępstwo prezydenta jest sprawowane przez wiceprezydenta, który w razie opróżnienia urzędu głowy państwa zostaje prezydentem do czasu, który pozostał do końca kadencji ${ }^{16}$. Model ten doczekał się szerokiej recepcji, szczególnie w państwach Ameryki Południowej, ale również, co zostanie przedstawione w dalszych rozważaniach, w licznych państwach Azji i Afryki, choć oczywiście nie zawsze przyjęcie przez nie instytucji wiceprezydenta oznaczało powielenie wszystkich rozwiązań konstytucji USA dotyczących zastępstwa głowy państwa.

Dość skomplikowany model zastępstwa prezydenta przewiduje konstytucja Meksyku. Zgodnie z jej postanowieniami, jeśli opróżnienie urzędu nastąpiłoby w czasie pierwszych dwóch lat kadencji urzędującego prezydenta, Kongres (dwuizbowy parlament) ma wybrać tymczasowego prezydenta, a następnie w terminie maksymalnie 18 miesięcy dokonać wyboru głowy państwa na nową kadencję. Gdyby jednak opróżnienie urzędu nastąpiło po upływie dwóch lat bieżącej kadencji, Kongres wybiera nowego prezydenta na cały okres, jaki pozostał do zakończenia

Art. 7 Konstytucji Francji z 1958 r., (w:), Konstytucje państw Unii..., op. cit., s. 274.

Art. 34 Konstytucji Grecji z 1975 r., (w:) Konstytucje państw Unii..., op. cit., s. 310.

Art. 59 Konstytucji Finlandii.

Art. 14 Konstytucji Irlandii.

XXV Poprawka do konstytucji USA z 1787 r., (w:) Konstytucja Stanów Zjednoczonych Ameryki, tłum. i wstęp A. Pułło, Warszawa 2002, s. 65-66. 
tejże kadencji. W razie przejściowej niemożności pełnienia urzędu przez prezydenta, Kongres dokonuje wyboru tymczasowego prezydenta, który ma w tym okresie pełnić zastępstwo głowy państwa. Gdyby zaistniała konieczność zastępstwa prezydenta, a nie trwała akurat sesja Kongresu, wyboru osoby sprawującej zastępstwo ma dokonać Stała Komisja Kongresu ${ }^{17}$.

Każde pośród republikańskich państw basenu Morza Karaibskiego odmiennie rozwiązało kwestię zastępstwa głowy państwa. Na Haiti zastępstwo to sprawuje kolegialnie Rada Ministrów pod przewodnictwem premiera ${ }^{18}$. Konstytucja Kostaryki przewiduje istnienie dwóch wiceprezydentów, którzy zastępują głowę państwa w „porządku swej nominacji”, bądź, w przypadku przejściowej niemożności pełnienia urzędu przez prezydenta w porządku oznaczonym przez niego samego - jeśli oczywiście jest w stanie dokonać takiego aktu. Dwóch wiceprezydentów istnieje również w systemie ustrojowym Kuby, przy czym jeden z nich nosi tytuł pierwszego wiceprezydenta $\mathrm{i}$ to do niego należy sprawowanie zastępstwa głowy państwa ${ }^{19}$. W Trinidadzie i Tobago funkcję tę ma pełnić natomiast przewodniczący Senatu ${ }^{20}$.

\section{Ameryka Południowa}

Zdecydowana większość państw Ameryki Południowej przyjęła w swych konstytucjach system rządów wzorowany na rozwiązaniach istniejących w USA. W konsekwencji na kontynencie tym dominującym modelem zastępstwa prezydenta jest regulacja, polegająca na funkcjonowaniu urzędu wiceprezydenta, którego piastun zastępuje prezydenta $\mathrm{w}$ razie przejściowej niemożności pełnienia przez niego swych funkcji. W zasadzie jedynym zdecydowanym wyjątkiem od tej zasady jest rozwiązanie istniejące w Chile. Zgodnie z konstytucją zastępstwo prezydenta jest tam sprawowane przez urzędującego ministra, któremu funkcja ta przypada zgodnie z porządkiem pierwszeństwa określonym przez ustawę. Minister ów przyjmuje tytuł wiceprezydenta ${ }^{21}$. Zgodnie z odpowiednią ustawą z 2011 r. - istnieje następujący prawny porządek pierwszeństwa ministrów w sprawowaniu zastępstwa prezydenta: Minister Spraw Wewnętrznych, Minister Spraw Zagranicznych, Minister Obrony Narodowej, Minister Skarbu i pozostali ministrowie ${ }^{22}$. W sytuacji braku ministrów

\footnotetext{
17 Art. 84-85 Konstytucji Meksyku z 1917 r.; wersja angielska: https://www.constituteproject.org/constitution/Mexico_2007\#s969 (data dostępu: 30.06.2015 r.).

18 Art. 148-149 Konstytucji Haiti z 1987 r.; wersja angielska: https://www.constituteproject.org/constitution/Haiti_2012\#s833 (data dostępu: 30.06.2015 r.).

19 Art. 94 Konstytucji Kuby z 1976 r.; wersja angielska: https://www.constituteproject.org/constitution/Cuba_2002\#s572 (data dostępu: 30.06.2015 r.).

20 Art. 27 Konstytucji Trynidadu i Tobago z 1976 r.; wersja angielska: https://www.constituteproject.org/constitution/ Trinidad_and_Tobago_2007\#s342 (data dostępu: 30.06.2015 r.).

21 Art. 29 Konstytucji Chile z 1980 r., (w:) Konstytucja Chile, tłum. A. Wojtyczek-Bonnand, wstęp K. Wojtyczek, Warszawa 2012, s. 93-94. Ibidem, s. 93.
} 
prezydenta zastępują w następującej kolejności przewodniczący Senatu, przewodniczący Izby Deputowanych i przewodniczący Sądu Najwyższego.

Pewną specyfiką charakteryzuje się sposób rozwiązania zastępstwa prezydenta w Gujanie. W wypadku gdy prezydent nie jest w stanie sprawować swych funkcji, może on wyznaczyć swego zastępcę spośród członków swego Gabinetu - który musi być wszakże jednocześnie deputowanym do parlamentu. W razie gdyby prezydent nie był w stanie wyznaczyć zastępcy oraz w razie opróżnienia urzędu - zastępstwo głowy państwa jest w Gujanie sprawowane przez premiera ${ }^{23}$. Należy jednak zwrócić uwagę, iż premier nie jest w tym państwie szefem rządu, a jedynie „pierwszym spośród doradców" prezydenta. Ponadto z urzędu pełni on funkcję wiceprezydenta jakkolwiek głowa państw może też powołać innych wiceprezydentów, (którzy wchodzą w skład Gabinetu). Konstytucja Peru przewiduje obligatoryjnie istnienie dwóch wiceprezydentów, z których jeden nosi tytuł ,pierwszego wiceprezydenta” i on zastępuje $\mathrm{w}$ pierwszej kolejności prezydenta $\mathrm{w}$ razie niemożności sprawowania przez niego swych funkcji lub w razie opróżnienia urzędu ${ }^{24}$. Należy zresztą podkreślić, iż w przeciwieństwie do regulacji europejskich, większość konstytucji państw południowoamerykańskich zawiera odpowiednie rozwiązania na wypadek, gdyby osoba, która ma zastępować prezydenta nie była zdolna do realizacji tego obowiązku.

Zwrócić uwagę należy, iż w Chile jeśli opróżnienie urzędu prezydenta nastąpi, gdy pozostało mniej niż dwa lata do następnych wyborów prezydenckich, nowy prezydent jest wybierany przez Kongres, w przeciwnym zaś wypadku osoba zastępująca go wykonuje obowiązki głowy państwa przez okres, jaki pozostał do końca kaden$\mathrm{cji}^{25}$. Podobna regulacja obowiązuje w Wenezueli, gdzie w razie opróżnienia urzędu prezydenta w okresie pierwszych czterech lat (sześcioletniej) kadencji odbywają się nowe wybory, zaś w przypadku gdyby taka sytuacja nastąpiła w ciągu ostatnich dwu lat kadencji, wiceprezydent przejmuje urząd głowy państwa do jej zakończenia ${ }^{26}$.

\section{Azja i Oceania}

Republikańskie państwa Azji i Oceanii są zdecydowanie bardziej zróżnicowane w swych rozwiązaniach dotyczących zastępstwa prezydenta, aniżeli miało to miejsce w przypadku Europy i Ameryki Południowej. Generalnie jednak można wskazać tutaj na dość częstą recepcję dwóch modeli powszechnie funkcjonujących na wyżej wymienionych kontynentach, tzn. zastępstwa przez przewodniczącego parlamentu lub przez wiceprezydenta. Pierwsze z wymienionych rozwiązań

Art. 95 Konstytucji Gujany z 1980 r., wersja angielska: https://www.constituteproject.org/constitution/Guyana_1995\#s392 (data dostępu: 30.06.2015 r.).

Art. 115 Konstytucji Peru z 1993 r., wersja angielska: https://www.constituteproject.org/constitution/Peru_2009\#s542 (data dostępu: 30.06.2015 r.).

Art. 29 Konstytucji Chile.

Art. 233 Konstytucji Wenezueli z 1999 r., wersja angielska: https://www.constituteproject.org/constitution/Venezuela_2009\#s935 (data dostępu: 30.06.2015 r.). 
funkcjonuje m.in.: w Armenii ${ }^{27}$, Gruzji ${ }^{28}$, Kazachstanie ${ }^{29}$, Kirgistanie ${ }^{30}$, Mongolii ${ }^{31}$, Pakistanie $^{32}$, Syrii ${ }^{33}$, Tadżykistanie ${ }^{34}$, Timorze Wschodnim ${ }^{35}$, Uzbekistanie ${ }^{36}$ i Vanuatu $^{37}$. Jak widać, jest to model szczególnie chętnie recypowany w byłych republikach ZSRR. Z kolei model ,wiceprezydencki” został przyjęty w Afganistanie ${ }^{38}$, Chinach $^{39}$, na Filipinach ${ }^{40}$ (rozwiązania zawarte w tym państwie stanowią dokładną kopię odpowiednich postanowień konstytucji USA - co z uwagi na pozostawanie tego kraju pod kontrolą USA do uzyskania niepodległości w 1946 r. nie może zaskakiwać), w Indonezji ${ }^{41}$, Iraku ${ }^{42}$, Jemenie ${ }^{43}$, Mikronezji ${ }^{44}$, Nepalu $^{45}$, Tajwanie ${ }^{46}$ i Wietnamie $^{47}$. Tym samym przyjęły go państwa o bardzo odmiennych doświadczeniach historycznych i różnych kulturach prawnych. Konstytucja Birmy przewiduje istnienie dwóch wiceprezydentów - zastępstwo prezydenta przejmuje ten z nich, który

27 Art. 59 i art. 60 Konstytucji Armenii z 1995 r., wersja angielska: https://www.constituteproject.org/constitution/Armenia_2005\#s356 (data dostępu: 30.06.2015 r.).

28 Art. $7 \overline{6}$ Konstytucji Gruzji z 1995 r., wersja angielska: https://www.constituteproject.org/constitution/Georgia_2013\#s673 (data dostępu: 30.06.2015 r.).

29 Art. 47 Konstytucji Kazachstanu z 1995 r., wersja angielska: https://www.constituteproject.org/constitution/Kazakhstan_2011\#s347 (data dostępu 30.06.2015).

30 Art. $6 \overline{6}-68$ Konstytucji Kirgistanu z 2010 r., wersja angielska: https://www.constituteproject.org/constitution/Kyrgyz_Republic_2010\#s612 (data dostępu: 30.06.2015 r.).

31 Art. 37 Konstytucji Mongolii z 1992 r., wersja angielska: https://www.constituteproject.org/constitution/Mongolia_2001\#s374 (data dostępu: 30.06.2015 r.).

32 Art. 49 Konstytucji Pakistanu z 1949 r., wersja angielska: https://www.constituteproject.org/constitution/Pakistan_2015\#s406 (data dostępu: 30.06.2015 r.).

33 Art. 92-93 Konstytucji Syrii z 1973 r., wersja angielska: https://www.constituteproject.org/constitution/Syria_2012\#s391 (data dostępu: 30.06.2015 r.).

34 Art. 71 Konstytucji Tadżykistanu z 1971 r., wersja angielska: https://www.constituteproject.org/constitution/Tajikistan_2003\#s331 (data dostępu: 30.06.2015 r.).

35 Art. 82 i art. 84 Konstytucji Timoru Wschodniego z 2002 r., wersja angielska: https://www.constituteproject.org/ constitution/East_Timor_2002\#s597 (data dostępu: 30.06.2015 r.).

36 Art. 96 Konstytucji Uzbekistanu z 1992 r., wersja angielska: https://www.constituteproject.org/constitution/Uzbekistan_2011\#s463 (data dostępu: 30.06.2015 r.).

37 Art. 37 Konstytucji Vanuatu z 1980 r., wersja angielska: https://www.constituteproject.org/constitution/Vanuatu_1983\#s270 (data dostępu: 30.06.2015 r.).

38 Art. 67 Konstytucji Afganistanu z 2004 r., wersja angielska: https://www.constituteproject.org/constitution/Afghanistan_2004\#s212 (data dostępu: 30.06.2015 r.).

39 Art. 84 Konstytucji Chin z 1982 r., wersja angielska: https://www.constituteproject.org/constitution/China_2004\#s352 (data dostępu: 30.06.2015 r.).

40 Art. VIII sekcja 8 Konstytucji Filipin z 1987 r., wersja angielska: https://www.constituteproject.org/constitution/Philippines_1987\#s299 (data dostępu: 30.06.2015 r.).

41 Art. 8 Konstytucji Indonezji z 1945 r., wersja angielska: https://www.constituteproject.org/constitution/Indonesia_2002\#s79 (data dostępu: 2.07.2015 r.).

42 Art. 75 Konstytucji Iraku z 2005 r., wersja angielska: https://www.constituteproject.org/constitution/ Iraq_2005\#s503 (data dostępu: 2.07.2015 r.).

43 Art. 116 Konstytucji Jemenu z 1992 r., wersja angielska: https://www.constituteproject.org/constitution/ Yemen_2001\#s314 (data dostępu: 2.07.2015 r.).

44 Art. X sekcja 6 Konstytucji Mikronezji z 1981 r., wersja angielska: https://www.constituteproject.org/constitution/ Micronesia_1990\#s201 (data dostępu: 2.07.2015 r.).

45 Art. $36 \mathrm{G}$ Konstytucji Nepalu z 2006 r., wersja angielska: https://www.constituteproject.org/constitution/Nepal_2012\#s399 (data dostępu: 2.07.2015 r.).

46 Art. 49 Konstytucji Tajwanu z 1947 r., wersja angielska: https://www.constituteproject.org/constitution/Taiwan_2005\#s152 (data dostępu: 2.07.2015 r.).

47 Art. 93 Konstytucji Wietnamu z 1992 r., wersja angielska: https://www.constituteproject.org/constitution/Socialist_ Republic_of_Vietnam_2013\#s556 (data dostępu: 2.07.2015 r.). 
uzyskał największą liczbę głosów w wyborach ${ }^{48}$. Dwóch wiceprezydentów funkcjonuje również w Afganistanie, a kolejność, w jakiej przejmują oni zastępstwo głowy państwa określa sam prezydent ${ }^{49}$. Oczywiście w Azji i Oceanii nie brak także rozwiązań oryginalnych, często występujących tylko w jednym kraju. Jako przykład można tu wskazać Sri Lankę ${ }^{50}$, w którym to kraju osobę zastępującą prezydenta wybiera parlament spośród swoich członków. Na Fidżi zastępstwo prezydenta sprawuje Prezes Sądu Najwyższego ${ }^{51}$, zaś na Wyspach Marshalla zastępca prezydenta zostaje mianowany przez przewodniczącego (Speakera) parlamentu na wniosek Gabinetu Ministrów i spośród jego członków ${ }^{52}$. Na Samoa głowę państwa (zwaną O le Ao o le $M_{a l o}{ }^{53}$ ) zastępuje Rada Zastępców wybierana przez parlament (spośród osób posiadających bierne prawo wyborcze na urząd głowy państwa) - mimo swej „kolegialnej” nazwy organ ten może mieć jednak charakter jednoosobowy ${ }^{54}$. W Singapurze zastępstwo prezydenta jest wykonywane przez przewodniczącego rady doradców prezydenckich $^{55}$. Na Kiribati zastępstwo głowy państwa określanej jako Beretitenti sprawuje piastun urzędu zwanego Kauoman-ni-Beretitenti, który jest odpowiednikiem wiceprezydenta. Jednakże Beretitenti podlega odpowiedzialności politycznej przed parlamentem i jeśli na skutek jej egzekwowania zostaje odwołany, jego zastępstwo sprawuje Rada Państwa składająca się z Szefa Komisji Służby Publicznej (sprawującej stałą kontrolę nad prawidłowym działaniem administracji), Prezesa Sądu Najwyższego i Przewodniczącego (Speakera) parlamentu. Ponadto przejęcie urzędu głowy państwa przez Kauoman-ni-Beretitenti w razie, jeśli urząd ten został opróżniony z innych przyczyn niż odpowiedzialność polityczna, wymaga akceptacji przez parlament, a jeśli nie zostanie ona udzielona odbywają się nowe wybory ${ }^{56}$. Do specyficznych na gruncie azjatyckim zaliczyć należy także rozwiązania Azerbej-

48 Art. 73 Konstytucji Birmy z 2008 r., wersja angielska: https://www.constituteproject.org/constitution/Myanmar_2008\#s449 (data dostępu: 2.07.2015 r.).

49 Art. 67 Konstytucji Afganistanu.

50 Art. 38 i art. 40 Konstytucji Sri Lanki z 1978 r., wersja angielska: https://www.constituteproject.org/constitution/ Sri_Lanka_2010\#s490 (data dostępu: 2.07.2015 r.).

51 Art. 88 Konstytucji Fidżi z 2013 r., wersja angielska: https://www.constituteproject.org/constitution/ Fiji 2013\#s1498 (data dostępu: 2.07.2015 r.). Art. V sekcja 9 Konstytucji Wysp Marshalla z 1979 r., wersja angielska: https://www.constituteproject.org/constitution/Marshall_Islands_1995\#s652 (data dostępu: 2.07.2015 r.).

53 Należy tu zaūważyć, iż kwestią sporną jest czy głowa państwa na Samoa jest monarchą czy też prezydentem zob. P. Osóbka, Systemy Konstytucyjne państw Oceanii, Warszawa 2012, s. 51.

54 Art. 23-25 Konstytucji Samoa z 1962 r.; wersja angielska: https://www.constituteproject.org/constitution/Samoa_2013\#s231 (data dostępu 2.07.2015 r.).

55 Art. $22 \mathrm{~N}$ Konstytucji Singapuru z 1963 r., wersja angielska: https://www.constituteproject.org/constitution/Singapore_2010\#s653 (data dostępu: 2.07.2015 r.).

56 Art. $35-36$ Konstytucji Kiribati z 1979 r., wersja angielska: https://www.constituteproject.org/constitution/Kiribati_1995\#s520 (data dostępu: 2.07.2015 r.). 
dżanu $^{57}$ i Korei Południowej ${ }^{58}$, w których zastępstwo prezydenta jest sprawowane przez premiera.

Jako charakterystyczną cechę rozwiązań republikańskich państw azjatyckich w zakresie zastępstwa głowy państwa wskazać należy częstsze wprowadzanie bardziej szczegółowych niż w Europie i Ameryce Południowej regulacji dotyczących badania stanu zdrowia prezydenta w celu stwierdzenia, czy jest on zdolny do pełnienia swych funkcji. Szczególnie rozbudowane normy w tym zakresie zawierają konstytucje większości byłych azjatyckich republik ZSRR (Uzbekistan ${ }^{59}$, Kirgistan $^{60}$, Tadżykistan $^{61}$, Turkmenistan ${ }^{62}$ ). Podobne regulacje przewidują również ustawy zasadnicze Samoa ${ }^{63}$ i Sri Lanki ${ }^{64}$ - przy czym w obydwu tych państwach stosowne postępowanie jest prowadzone pod nadzorem Prezesa Sądu Najwyższego. Zaznaczyć również należy, iż państwa azjatyckie często wprowadzają w swych konstytucjach rozbudowane normy regulujące sytuacje, gdyby osoba, która ma zastępować prezydenta, nie mogła realizować tej funkcji.

\section{Afryka}

Państwa Afryki wykazują chyba największe zróżnicowanie rozwiązań w omawianej materii. Najogólniej rzecz biorąc, w Afryce występują trzy modele zastępstwa republikańskiej głowy państwa:

- ,europejski”, tzn. sprawowanie zastępstwa przez przewodniczącego parlamentu lub jednej z jego izb (m.in. Algieria ${ }^{65}$, Madagaskar ${ }^{66}$, Mozambik $^{67}$, Senegal $^{68}$, Wybrzeże Kości Słoniowej $\left.{ }^{69}\right)$;

57 Art. 105 Konstytucji Azerbejdżanu z 1995 r., wersja angielska: https://www.constituteproject.org/constitution/ Azerbaijan_2009\#s774 (data dostępu: 2.07.2015 r.).

58 Art. 71 Konstytucji Korei Południowej z 1948 r., wersja angielska: https://www.constituteproject.org/constitution/ Republic_of_Korea_1987\#s370 (data dostępu: 2.07.2015 r.).

59 Art. 96 Konstytucji Uzbekistanu.

60 Art. 66 Konstytucji Kirgistanu.

61 Art. 71 Konstytucji Tadżykistanu.

62 Art. 57 Konstytucji Turkmenistanu.

63 Art. 23 Konstytucji Samoa.

64 Art. 38 Konstytucji Sri Lanki.

65 Art. 88 Konstytucji Algierii z 1989 r., wersja angielska: https://www.constituteproject.org/constitution/Algeria_2008\#s355 (data dostępu: 3.07.2015 r.).

66 Art. 50-53 Konstytucji Madagaskaru z 2010 r., wersja angielska: https://www.constituteproject.org/constitution/ Madagascar_2010\#s217 (data dostępu: 3.07.2015 r.).

67 Art.151-152 Konstytucji Mozambiku z 2004 r., wersja angielska: https://www.constituteproject.org/constitution/ Mozambique_2007\#s1017 (data dostępu: 3.07.2015 r.).

68 Art.39 Konstytucji Senegalu z 2001 r., wersja angielska: https://www.constituteproject.org/constitution/Senegal_2009\#s157 (data dostępu: 3.07.2015 r.).

69 Art. 40 Konstytucji Wybrzeża Kości Słoniowej z 2000 r.; https://www.constituteproject.org/constitution/Cote_Dlvoire_2004\#s98 (data dostępu: 3.07.2015 r.). 
- model sprawowania zastępstwa przez wiceprezydenta (m.in. Angola ${ }^{70}$, Ghana $^{71}$, Nigeria ${ }^{72}$, RPA $^{73}$, Uganda ${ }^{74}$, Zimbabwe ${ }^{75}-$ kilku wiceprezydentów występuje w Burundi ${ }^{76}$, Malawi ${ }^{77}$ i Sudanie ${ }^{78}$ );

- specyficzny dla Afryki model, który można określić jako „podzielony” polega on na tym, iż w razie przejściowej niemożności sprawowania przez prezydenta swych funkcji jego zastępstwo sprawuje szef rządu, zaś w razie opróżnienia urzędu prezydenckiego jest ono wykonywane przez przewodniczącego parlamentu lub jednej z jego izb (model ten funkcjonuje w Burkina Faso $^{79}$, Egipcie $^{80}$, Mali ${ }^{81}$, Rwandzie ${ }^{82}$ i Tunezji $\left.{ }^{83}\right)$.

W tym miejscu warto zwrócić uwagę, iż dla znacznej części państw, które w przeszłości stanowiły kolonie francuskie charakterystyczna jest recepcja modelu byłej metropolii w postaci przyjęcia regulacji polegającej na tym, iż zastępstwo prezydenta sprawuje przewodniczący Senatu (Senegal ${ }^{84}$, Kamerun ${ }^{85}$, Burkina Faso ${ }^{86}$, Madagaskar ${ }^{87}$ ). Spotykanym na tym kontynencie rozwiązaniem jest obecność w konstytucjach rozbudowanych, a nieraz wręcz kazuistycznych procedur stwierdzania stanu zdrowia prezydenta. Niektóre ustawy zasadnicze przewidują powołanie w tym celu komisji medycznych, a nawet precyzyjnie określają ich skład (np. Nigeria ${ }^{88}$,

Art. 131-132 Konstytucji Angoli z 2010 r., wersja angielska: https://www.constituteproject.org/constitution/Angola_2010\#s1195 (data dostępu: 3.07.2015 r.).

Art. 60 Konstytucji Ghany z 1992 r., wersja angielska: https://www.constituteproject.org/constitution/Ghana_1996\#s958 (data dostępu: 3.07.2015 r.).

Art. 145-146 Konstytucji Nigerii z 1999 r., wersja angielska: https://www.constituteproject.org/constitution/Nigeria_1999\#s1639 (data dostępu: 3.07.2015 r.).

Art. 90 Konstytucji RPA z 1996 r., wersja angielska: https://www.constituteproject.org/constitution/South_Africa_2012\#s1441 (data dostępu: 3.07.2015 r.).

Art. 109 Konstytucji Ugandy z 1995 r., wersja angielska: https://www.constituteproject.org/constitution/Uganda_2005\#s1582 (data dostępu: 3.07.2015 r.).

Art. 94 i art. 100 Konstytucji Zimbabwe z 2013 r., wersja angielska: https://www.constituteproject.org/constitution/ Zimbabwe_2013\#s1239 (data dostępu: 3.07.2015 r.).

Art. 121 Konstytucji Burundi z 2005 r., wersja angielska: https://www.constituteproject.org/constitution/Burundi_2005\#s360 (data dostępu: 3.07.2015 r.).

Art. 87 Konstytucji Malawi, wersja angielska: https://www.constituteproject.org/constitution/Malawi_1999\#s992 (data dostępu: 3.07.2015 r.).

Art. 66-67 Konstytucji Sudanu z 2005 r., wersja angielska: https://www.constituteproject.org/constitution/Sudan_2005\#s517 (data dostępu: 3.07.2015 r.).

Art. 43 Konstytucji Burkina Faso z 1991 r., wersja angielska: https://www.constituteproject.org/constitution/Burkina_Faso_2012\#s153 (data dostępu: 3.07.2015 r.).

Art. 160 Konstytucji Egiptu z 2014 r., wersja angielska: https://www.constituteproject.org/constitution/ Egypt 2014\#s518 (data dostępu: 3.07.2015 r.).

Art. 36 Konstytucji Mali z 1992 r., wersja angielska: https://www.constituteproject.org/constitution/Mali_1992\#s129 (data dostępu: 3.07.2015 r.).

Art. 107 Konstytucji Rwandy z 2003 r., wersja angielska: https://www.constituteproject.org/constitution/Rwanda_2010\#s567 (data dostępu: 3.07.2015 r.).

Art. 83-85 Konstytucji Tunezji z 2014 r., wersja angielska: https://www.constituteproject.org/constitution/Tunisia_2014\#s326 (data dostępu: 3.07.2015 r.).

Art.39 Konstytucji Senegalu

Art. 6 Konstytucji Kamerunu z 1972 r., wersja angielska: https://www.constituteproject.org/constitution/Cameroon_2008\#s108 (data dostępu: 3.07.2015 r.).

Art. 43 Konstytucji Burkina Faso.

Art. 52 Konstytucji Madagaskaru.

Art.144 Konstytucji Nigerii. 
Tanzania $^{89}$, Seszele $^{90}$ ). Podobnie jak to było w kilku państwach azjatyckich, również niektóre afrykańskie systemy ustrojowe przewidują, iż dochodzenie w sprawie ustalenia stanu zdrowia głowy państwa będzie przeprowadzane przez Sąd Najwyższy (np. Seszele ${ }^{91}$, Tanzania ${ }^{92}$ ).

Spośród rozwiązań specyficznych nie przystających do żadnego ze wskazanych wyżej modeli wskazać należy na regulację zawartą w konstytucji Libanu, zgodnie z którą zastępstwo prezydenta sprawuje rząd in corpore ${ }^{93}$. Podobnie oryginalny charakter na tle całego kontynentu mają rozwiązania Dżibuti - w którym zastępstwo głowy państwa należy do Prezesa Sądu Najwyższego ${ }^{94}$ oraz Gwinei Równikowej gdzie funkcję tę spełnia komisja złożona z przewodniczącego parlamentu (który kieruje jej pracami), premiera, Prezesa Sądu Najwyższego oraz członka sądu konstytucyjnego delegowanego do prac w komisji przez prezesa tegoż sądu' ${ }^{95}$. Ciekawe rozwiązanie zostało przyjęte w Sudanie, gdzie istnieją stanowiska pierwszego wiceprezydenta i drugiego wiceprezydenta, lecz zastępstwo głowy państwa sprawuje Rada Prezydencka, w skład której wchodzą obydwaj wiceprezydenci oraz przewodniczący parlamentu ${ }^{96}$. Wreszcie należy wskazać na przykład Namibii, będącej jedynym państwem afrykańskim, w którym to szefowi rządu powierzono sprawowanie zastępstwa głowy państwa zarówno w przypadku przejściowej niemożności sprawowania przez prezydenta swych funkcji, jak również w razie opróżnienia urzędu prezydenckiego ${ }^{97}$. Państwa afrykańskie, podobnie jak to miało miejsce w Azji i Oceanii, często wprowadzają $\mathrm{w}$ swych konstytucjach rozbudowane normy regulujące sytuacje, gdyby osoba, która w pierwszej kolejności ma zastępować prezydenta, nie była zdolna, aby to uczynić

\section{Zakończenie}

Przedstawione powyżej rozważania z natury rzeczy nie odnoszą się do wielu kwestii szczegółowych dotyczących zastępstwa republikańskiej głowy państwa. Jednak już wstępny zarys omawianego problemu przedstawiony w niniejszej pracy wskazuje, iż rozwiązania przyjmowane przez poszczególne państwa cechuje zara-

Art. 37 Konstytucji Tanzanii z 1977 r., wersja angielska: https://www.constituteproject.org/constitution/Tanzania_1995\#s407 (data dostępu: 3.07.2015 r.).

90 Art. 53 Konstytucji Seszeli z 1993 r., wersja angielska: https://www.constituteproject.org/constitution/Seychelles_2011\#s805 (data dostępu: 3.07.2015 r.).

91 Ibidem.

92 Art. 37 Konstytucji Tanzanii.

93 Art. 62 Konstytucji Libanu z 1926 r., wersja angielska: https://www.constituteproject.org/constitution/Lebanon_2004\#s276 (data dostępu: 3.07.2015 r.).

94 Art. 29 Konstytucji Dżibuti z 1992 r., wersja angielska: https://www.constituteproject.org/constitution/Djibouti_2010\#s106 (data dostępu: 3.07.2015 r.).

95 Art. 43 Konstytucji Gwinei Równikowej z 1991 r., wersja angielska: https://www.constituteproject.org/constitution/ Equatorial_Guinea_1995\#s267 (data dostępu: 3.07.2015 r.).

96 Art. 66-67 Konstytucji Sudanu.

97 Art. 34 Konstytucji Namibii z 1990 r., wersja angielska: https://www.constituteproject.org/constitution/Namibia_2010\#s478 (data dostępu: 3.07.2015 r.). 
zem różnorodność przyjętych rozwiązań, jak również tendencja do recypowania określonych modeli $\mathrm{i}$ to nie tylko $\mathrm{w}$ ramach jednego obszaru geograficznego, ale także pomiędzy nimi (vide recepcja modelu USA w państwach innych kontynentów). Niewątpliwie zagadnienie to $\mathrm{z}$ uwagi na swoją złożoność wymaga dalszych badań, w szczególności dotyczących przyczyny popularności recepcji określonych modeli, jak również stosowania omawianych regulacji w praktyce.

\section{BIBLIOGRAFIA}

Konstytucja Austrii z 1920 r. [w:] 2011. Konstytucje państw Unii Europejskiej, pod red. Wiesława Staśkiewicza, Warszawa: Wydawnictwo Sejmowe.

Konstytucja Bułgarii z 1991 r. [w:] 2012.Konstytucja Bułgarii, thum. A. Kubik, wstęp J. Karp, Warszawa: Wydawnictwo Sejmowe.

Konstytucja Chile z 1980 r., [w:] 2012. Konstytucja Chile , thum. A. Wojtyczek-Bonnand, wstęp K. Wojtyczek, Warszawa: Wydawnictwo Sejmowe.

Konstytucja Czech z 1992 r. [w:] 2011. Konstytucje państw Unii Europejskiej, pod red. Wiesława Staśkiewicza, Warszawa: Wydawnictwo Sejmowe.

Konstytucja Federacji Rosyjskiej z 1993 r. [w:] 2000. Konstytucja Rosji. thum. Andrzej Kubik, wstęp A. Bosiacki, Warszawa: Wydawnictwo Sejmowe.

Konstytucja Finlandii z 1999 r. [w:] 2011. Konstytucje państw Unii Europejskiej, pod red. Wiesława Staśkiewicza, Warszawa: Wydawnictwo Sejmowe.

Konstytucja Francji z 1958 r. [w:] 2011. Konstytucje państw Unii Europejskiej, pod red. Wiesława Staśkiewicza, Warszawa: Wydawnictwo Sejmowe.

Konstytucja Grecji z 1975 r. [w:] 2011. Konstytucje państw Unii Europejskiej, pod red. Wiesława Staśkiewicza, Warszawa: Wydawnictwo Sejmowe.

Konstytucja Irlandii z 1937 r. [w:] 2011.Konstytucje państw Unii Europejskiej, pod red. Wiesława Staśkiewicza, Warszawa: Wydawnictwo Sejmowe.

Konstytucja Islandii z 1944 r. [w:] 2000. Konstytucja Islandii, thum. i wstęp J. Osiński Warszawa: Wydawnictwo Sejmowe.

Konstytucja Malty [w:] 2011. Konstytucje państw Unii Europejskiej, pod red. Wiesława Staśkiewicza, Warszawa: Wydawnictwo Sejmowe.

Konstytucja Słowacji z 1992 r. [w:] 2011. Konstytucje państw Unii Europejskiej, pod red. Wiesława Staśkiewicza, Warszawa: Wydawnictwo Sejmowe.

Konstytucja USA z 1787 r. [w:] 2002. Konstytucja Stanów Zjednoczonych Ameryki, tłum. i wstęp A. Pułło, Warszawa: Wydawnictwo Sejmowe.

Osóbka Przemysław. 2012. Systemy Konstytucyjne państw Oceanii, Warszawa: Wydawnictwo Sejmowe.

Zubik Marek.2010. Gdy Marszałek Sejmu. jest pierwszą osobą w państwie, czyli polskie interregnum, Przegląd Sejmowy 100 (5): 71-89. 


\section{METHODS OF REGULATION FOR DEPUTISING THE HEAD OF STATE IN CONTEMPORARY REPUBLICS IN THE EVENT OF THE OFFICE FALLING VACANT IN MID-TERM OR IN CASES WHERE THE INCUMBENT HEAD OF STATE IS TEMPORARILY UNABLE TO DISCHARGE HIS DUTIES. SOLUTIONS "TYPICAL" AND "ORIGINAL"}

The Smolensk air disaster in 2010, acts as a pointed reminder to the importance of constitutional regulations in preparing for the occurrence of emergencies and maintaining functionality of the supreme organs of state. The purpose of this article is to present the solutions adopted by modern-day republics to replace the head of state in situations where the office becomes vacant in mid-term, or where the head of state, for whatever reason, is no longer able to exercise the functions of office. The article identifies normative regulations contained in the constitutions of various republics connected with this issue. Special attention is devoted to identifying similarities between countries sharing the same circle of legal culture. The article also analyses constitutional provisions on this issue which are unusual in the context of global and regional norms.

Keywords: head of state, republic, replacement

Słowa kluczowe: głowa państwa, republika, zastępstwo 